\title{
The effect of long-term treatment with steroid hormones or tamoxifen on oestrogen receptors ( $\alpha$ and $\beta$ ) in the endometrium of ovariectomized cynomolgus macaques
}

\author{
H Wang, E Isaksson ${ }^{1}$, B von Schoultz ${ }^{2}$, J M Cline ${ }^{3}$ and L Sahlin \\ Division for Reproductive Endocrinology, Department of Woman and Child Health, Karolinska Hospital, 17176 Stockholm, Sweden \\ ${ }^{1}$ Department of Oncology, Radiumhemmet, Karolinska Hospital, 17176 Stockholm, Sweden \\ ${ }^{2}$ Division for Obstetrics and Gynaecology, Department of Woman and Child Health, Karolinska Hospital, 17176 Stockholm, Sweden \\ ${ }^{3}$ Department of Pathology, Section on Comparative Medicine, Wake Forest University School of Medicine, Winston-Salem, North Carolina, USA \\ (Requests for offprints should be addressed to H Wang; Email: Hong.Wang@cgb.ki.se)
}

\begin{abstract}
The effects of oestrogen are mediated by two specific intracellular receptors, oestrogen receptors (ER) $\alpha$ and $\beta$, which function as ligand-activated transcriptional regulators. Ovariectomized macaques (Macaca fascicularis) were used to study the regulation of $\operatorname{ER} \alpha$ and $\operatorname{ER} \beta$ in the endometrium by immunohistochemistry and in situ hybridization after long-term hormone treatment. Animals were treated continuously for 35 months with either conjugated equine oestrogen (CEE), medroxyprogesterone acetate (MPA), combined CEE/MPA, or tamoxifen (TAM). Treatment with CEE/MPA down-regulated $\mathrm{ER} \alpha$ in the superficial glands. In the superficial stroma the ER $\alpha$ level was lower in the CEE/MPA group than in the
\end{abstract}

CEE and MPA groups. ER $\beta$ immunostaining was faint with minor variation in response to treatment, but increased in the superficial stroma after MPA treatment. The ratio of ER $\beta / E R \alpha$ increased in superficial stroma and gland after CEE/MPA treatment, and also in stroma after MPA and TAM. Cystic endometrial hyperplasia was observed in TAM-treated animals, in combination with a high level of ER $\alpha$ protein expression. The present data show that long-term hormone treatment affects the ER $\alpha$ and $\operatorname{ER} \beta$ protein levels in the endometrium. The balance between $\operatorname{ER} \alpha$ and $\operatorname{ER} \beta$ seems to be important for the proliferative response to oestrogen.

Journal of Endocrinology (2002) 175, 673-681

\section{Introduction}

Oestrogens have important effects on normal cell growth, differentiation and malignant progression in many reproductive tissues including the mammary gland (Henderson et al. 1982). Oestrogen alone or different combinations of oestrogen and progestogen are commonly used for reducing the menopausal symptoms among postmenopausal women on hormone replacement therapy (HRT), but are associated with a durationdependent increased risk of endometrial carcinoma (Grady et al. 1992, 1995). In addition, others have shown that both progestogen-only contraception and continuous-combined HRT reduce endometrial cancer risk (Vihko \& Isomaa 1989, Pike \& Ross 2000). The anti-oestrogen tamoxifen (TAM) is the most commonly used treatment for patients with oestrogen receptor (ER)-positive breast cancers. TAM has opposite effects in different organs, acting as an oestrogen antagonist with antiproliferative effects in breast (Rose et al. 1985), while having agonistic effects in the endometrium (Helgason et al. 1982, Katzenellenbogen \&
Katzenellenbogen 1996). Women receiving long-term TAM therapy have an increased risk of developing endometrial cancer (Malfetano 1990). The association between HRT or TAM treatment and endometrial cancer is still not clearly understood.

The effects of oestrogen are mediated by two specific intracellular receptors, ER $\alpha$ and $E R \beta$, functioning as ligand-activated transcriptional regulators. Although the affinity of $E R \beta$ for oestradiol $\left(E_{2}\right)$ is similar to that of $E R \alpha$, they have different affinities for other oestrogen agonists and antagonists (Kuiper et al. 1996). The regulation of cellular responses is complex, since ERs not only mediate endocrine but also paracrine and autocrine signals (Dickson \& Lippman 1987). Both in vitro and in vivo studies have suggested that human ER modulates the transcriptional activity of ER (Hall \& McDonnell 1999, Weihua et al. 2000) and is a key determinant of cellular responses to agonists and antagonists (Hall \& McDonnell 1999).

Oestrogens exert their effects in the target organs by binding to the receptors thereby modulating the expression of various proteins such as growth factors (Murphy \& Ghahary 1990). 
Table 1 Hormone levels in each group (means \pm S.E.M.)

\begin{tabular}{|c|c|c|c|c|c|}
\hline & OVX $(n=5)$ & CEE $(n=4)$ & MPA $(n=5)$ & CEE/MPA $(n=5)$ & $\operatorname{TAM}(n=6)$ \\
\hline MPA $(\mathrm{pg} / \mathrm{ml})$ & $0 \cdot 0 \pm 0 \cdot 0$ & $11 \cdot 2 \pm 7 \cdot 4$ & $81 \cdot 7 \pm 11 \cdot 5$ & $76 \cdot 4 \pm 10 \cdot 8$ & $30 \cdot 0 \pm 7 \cdot 4$ \\
\hline
\end{tabular}

The distribution and regulation of $\operatorname{ER} \alpha$ have been extensively studied in several mammalian species (Clark et al. 1992). A few studies have shown ER $\beta$ expression in the endometrium of monkeys (Pelletier et al. 1999, Critchley et al. 2001) and humans (Matsuzaki et al. 1999, Critchley et al. 2001, Lecce et al. 2001) with a cyclic change during the menstrual cycle. The data suggest that ER $\beta$ may have important roles in endometrial function in humans and nonhuman primates. However, no studies have been performed comparing regulation of ER $\alpha$ and $\operatorname{ER} \beta$ in the endometrium after long-term hormone treatment.

Macaques are similar to human beings in many aspects of reproductive biology such as endometrial responses to exogenous oestrogen (Brenner \& Slayden 1994), sex steroid receptor expression (Brenner et al. 1990) and expression of oestrogen- and progestin-regulated genes (Ace \& Okulicz 1995). The aim of this study was to compare the expression of $\operatorname{ER} \alpha$ and $\operatorname{ER} \beta$ in the endometrium after long-term exposure to conjugated equine oestrogen (CEE), medroxyprogesterone acetate (MPA), CEE/MPA or TAM by using ovariectomized (OVX) animals. The results will give an indication of the effects of HRT and possible explanations for the different effects on the endometrium found after treatment with these compounds.

\section{Materials and Methods}

\section{Animals}

The 25 female adult cynomolgus macaques (Macaca fascicularis) used in this study were imported from Indonesia to the United States. All the macaques were 4-6 years old. They were housed in social groups of four to eight monkeys each in a facility. Bilateral ovariectomies were performed 3 months before initiation of hormone treatment. Twenty monkeys were treated continuously with either $0.625 \mathrm{mg} /$ day CEE; $2.5 \mathrm{mg} /$ day MPA; the combination of CEE+MPA; or $20 \mathrm{mg} /$ day TAM. The compounds were administered in the diet for 35 months at doses equivalent, on a caloric basis, to those given to women (Adams et al. 1997). The animal study was approved by the Association for the Advancement and Accreditation of Laboratory Animal Care and Use Committee in the US.

\section{Hormone measurement}

Serum concentrations of $E_{2}$ and MPA were determined by RIA (Wilson et al. 1988). The TAM level was measured by HPLC described by Langan-Fahey et al. (1990).

\section{Tissue collection}

Uterine tissues were collected at the end of the treatment period, when all the animals were killed. Tissues were fixed in $4 \%$ paraformaldehyde for $24 \mathrm{~h}$ and stored at $4{ }^{\circ} \mathrm{C}$ in $70 \%$ ethanol. Thereafter tissues were trimmed to $3 \mathrm{~mm}$ in thickness and embedded in paraffin.

\section{Immunohistochemistry}

Paraffin sections $(5 \mu \mathrm{m})$ were used and a standard immunohistochemical technique (avidin-biotin-peroxidase) was carried out as described before (Wang et al. 1999) for immunolocalization of ER $\alpha$ and Ki67. A two-step indirect method (using an enzyme-labelled secondary antibody)

\footnotetext{
Figure 1 (Opposite) Immunohistochemical localization of ER $\alpha$ and ER $\beta$ in the endometrial stroma (Str), GE and LE. Positive immunostaining was present in the nuclei. The left column shows ER $\alpha$ in both superficial and basal layers of the endometrium in a representative animal from each group ((a) OVX; (d) CEE; (g) MPA; (j) CEE/MPA; and (m) TAM) at low magnification ( $\times 100$, bar $=100 \mu \mathrm{m})$. The middle column shows ER $\alpha$ in the superficial or basal layer at a high magnification $(\times 400$, bar $=20 \mu \mathrm{m})((\mathrm{b})$ OVX (superficial layer); (e) CEE (basal layer); (h) MPA (superficial layer); (k) CEE/MPA (basal layer); and (n) TAM (superficial layer)). The right column shows ER $\beta$ staining in the endometrium of a representative animal from each group ((c) OVX (superficial layer); (f) CEE (basal layer); (i) MPA (superficial layer; white arrow: positive vascular endothelial cells); (I) CEE/MPA (basal layer); and (o) TAM (superficial layer)) at a high magnification $(\times 400$, bar $=20 \mu \mathrm{m}$ ). (r) A negative control for ER $\beta$, incubated with the ER $\beta$ antibody pre-absorbed overnight with a synthetic ER peptide. (s) A positive control of ER $\beta$ staining as shown in breast tissue from an OVX monkey. Magnification $\times 400$ (bar $=20 \mu \mathrm{m})$. $(p$ and $q)$ Ki67 immunostaining $((p)$ OVX, $(q)$ CEE) at low magnification $(\times 100)$. A high magnification picture $(\times 400)$ is shown in the right corner.
} 


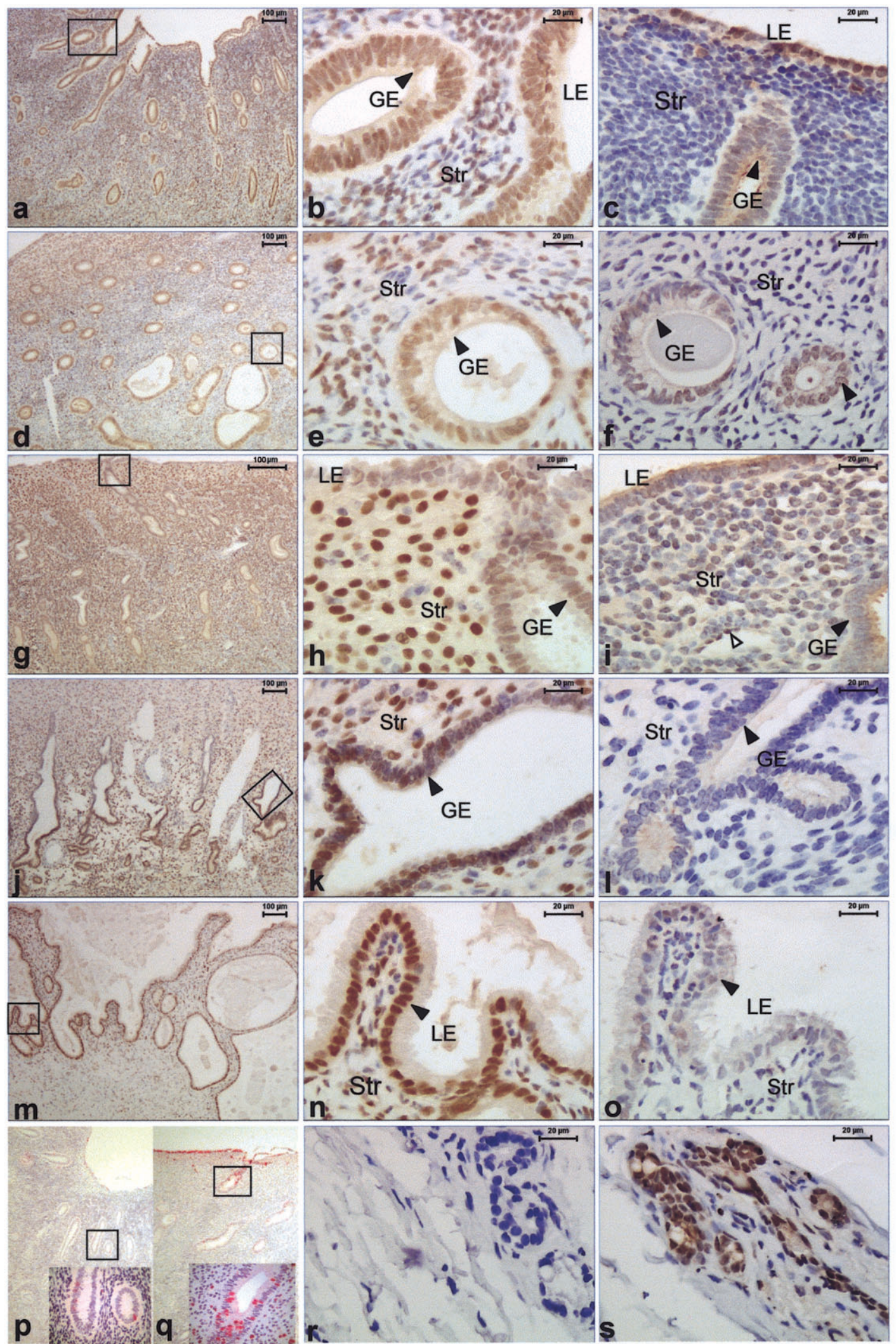


was carried out for ER $\beta$ immunostaining (Wang et al. 2001). The different immunostaining procedures for each specific antibody were performed as follows.

ER $\boldsymbol{\alpha}$ A monoclonal mouse antihuman antibody, recognizing the $\mathrm{A} / \mathrm{B}$ region, was used for detection of $\mathrm{ER} \alpha$ (08-1149; Zymed Laboratories, Inc., San Francisco, CA, USA). The primary antibody was incubated overnight at $4{ }^{\circ} \mathrm{C}$. The secondary antibody, biotinylated horse antimouse (BA-2000; Vector Laboratory, Burlingame, CA, USA) was incubated for $1 \mathrm{~h}$, and an avidin-biotinperoxidase complex for $1 \mathrm{~h}$ at room temperature (RT). Replacement of the primary antibody with an equivalent concentration of non-immune mouse $\operatorname{IgG}$ was used for negative controls of ER $\alpha$ immunostaining.

ER $\beta$ A polyclonal chicken $\operatorname{ER} \beta$ (503) antibody was used for the ER $\beta$ immunostaining. This antibody is directed against a hybrid between human and rat ER $\beta$. The preparation of this antibody was described by Saji et al. (2000).

Tissue sections were incubated with 1:500 dilution of ER $\beta$ antibody overnight at $4{ }^{\circ} \mathrm{C}$ in PBS with $3 \%$ BSA. To obtain negative controls, incubations were done with the ER $\beta$ antibody pre-absorbed with ER $\beta$ protein (Panvera, Madison, WI, USA) $\left(1: 50(\mathrm{v} / \mathrm{v})\right.$ overnight at $\left.4{ }^{\circ} \mathrm{C}\right)$. After washing, sections were incubated with peroxidaseconjugated rabbit anti-chicken IgG (A-9046; Sigma Chemical Co.) for $1 \mathrm{~h}$ at RT.

The peroxidase substrate diaminobenzidine was used to visualize the immunostaining reaction (SK 4100; Vector Laboratory). Thereafter the procedure was as described before (Wang et al. 1999).

Ki67 A monoclonal mouse antihuman antibody (MM-1) was used for Ki67 immunostaining (Novocastra, Newcastle upon Tyne, UK). The procedure was the same as that for ER $\alpha$ (see above). Vector Red (Vector Laboratory) was used to visualize the immunostaining reaction.

\section{Image analysis}

A Leica microscope and Sony video camera (Park Ridge, NJ, USA) connected to a computer with an image analysis system (Leica Imaging System Ltd, Cambridge, UK) were used to assess semi-quantitative values from ER $\alpha$ and $E R \beta$ immunohistochemistry. The quantification of immunostaining was performed as described previously (Wang et al. 1999). In short, by using colour discrimination software the total area of positively stained nuclei was measured, and expressed as a ratio of the total area of cell nuclei.

\section{Statistics}

Statistical calculations for the immunohistochemistry results were performed by ANOVA on ranks (KruskalWallis test) and significances were evaluated by Dunn's test. Values with different letter designations are significantly different $(P<0 \cdot 05)$.

\section{Results}

\section{Hormone levels}

The mean values for $E_{2}$, MPA and TAM in the serum of the monkeys in the different groups are shown in Table 1.

\section{Immunohistochemistry}

Immunohistochemistry showed that $\mathrm{ER} \alpha$ and $\mathrm{ER} \beta$ were present in the nuclei of cells in all compartments of the endometrium (Fig. 1). Variations were found in the levels of ERs between the superficial and basal layers of the endometrium. Hormone and TAM treatment induced changes in the histological features of the endometrium, e.g. CEE induced thickening of the endometrium and increased the glandular area fraction (Fig. 1d). MPA treatment did not induce distinguishable morphological changes (Fig. 1g) as compared with controls (Fig. 1a). TAM induced cystic endometrial hyperplasia (Fig. 1m).

ER $\boldsymbol{\alpha}$ In the OVX control group, ER $\alpha$ immunoreactivity was similar in the stroma of the superficial and basal layers (Fig. 1a and Fig. 2a and b). The ER $\alpha$ level was high in the superficial stroma in the CEE and MPA groups (Fig. 1d and $g$ and Fig. 2a), but was significantly decreased in the CEE/MPA group (Fig. 1j) as compared with the CEE and MPA groups (Fig. 2a). In addition, the superficial stroma cells in the CEE/MPA group showed decidualization, and $E R \alpha$ staining was faint (Fig. 1j). The variation in the ER $\alpha$ level in the basal stroma was less, except in the MPA group where the ER $\alpha$ level was significantly higher than in the OVX controls (Fig. 2b).

In the glandular epithelium (GE), over $95 \%$ of the nuclei stained positive for ER $\alpha$ in the OVX and TAM groups with no difference between the superficial and basal layers (Fig. 1a, b, m, n and Fig. 2c and d). In the glands of the superficial layer a gradual decrease of ER $\alpha$ immunoreactivity was observed in the CEE, MPA and CEE/MPA groups (Fig. 2c), although only to a significant level in the CEE/MPA group as compared with the OVX group (Fig. 2c). In the glands of the basal layer no differences between groups were found (Fig. 2d). Almost all epithelial cells were strongly positive after TAM treatment (Fig. $1 \mathrm{~m}$ and $\mathrm{n}$ and Fig. $2 \mathrm{c}-\mathrm{e}$ ). There was a significant difference in the luminal epithelium (LE) 
between the TAM- and MPA-treated animals (Fig. 2e). No immunostaining was found in the negative controls (data not shown).

ER $\beta$ Most ER $\beta$ immunostaining was faint in all compartments of the endometrium and in all study groups (Fig. 1c, f, i, 1, o). High immunoreactivity of ER $\beta$ was observed in the mammary gland of the same animals, which was used as a positive control in this study (Fig. 1s). The image analysis results imply less variations than in ER $\alpha$ levels both within and between the different groups, but the ER $\beta$ level in the superficial stroma after MPA treatment is significantly increased as compared with the OVX control (Fig. 1i and Fig. 3a).

It appears that overall ER $\beta$ immunoreactivity was higher in the LE (Fig. 3e) as compared with the stroma and glands (Fig. 3a-d). No specific nuclear staining was found in the negative control sections after incubation with a peptide corresponding to the epitope of the ER $\beta$ antibody (Fig. 1r).

The ratio of $E R \beta / E R \alpha$ immunoreactivity in the functionalis was estimated from the image analysis results and presented as means \pm S.E.M. (Table 2). The results imply that the ratio was increased in superficial stroma and GE after CEE/MPA treatment, and also in stroma after MPA and TAM treatment (Table 2), but it could not be statistically verified.

Ki67 The Ki67 immunostaining in the different treatment groups is shown in Table 3. The highest level of Ki67-positive cells was found in the superficial gland after CEE treatment (Fig. 1q and Table 3). The Ki67-positive staining was very low or absent in the basal stroma and glands. There were no significant differences observed between the groups (Fig. 1p and $\mathrm{q}$ and Table 3).

\section{Discussion}

Epidemiological studies have shown that continuouscombined oestrogen and progesterone $\left(\mathrm{P}_{4}\right)$ replacement therapy is not associated with any increased risk of endometrial cancer (Pike \& Ross 2000). This may be due to decreased endometrial cell proliferation caused by progestin in the uterus (Lane et al. 1986, Persson 2000). The present result and previously published data (Cline et al. 2001) demonstrated that 3 years of continuous oral treatment with CEE induced a marked glandular proliferation (increased Ki67 labelling) with thickening of the endometrium, and an increased glandular area fraction within the tissue. MPA reduced such proliferation and even reduced the CEE-stimulated proliferation when given in a continuous combined treatment with CEE (Cline et al. 2001). The decreased ER $\alpha$ level in the superficial GE and LE in this group implies that the MPA-antagonized epithelial proliferation could be due to a decrease in the ER $\alpha$ level. ER $\beta$ was found to be present in human endometrium with a decreased level in GE in the late secretory phase as compared with the other phases of the menstrual cycle (Critchley et al. 2001, Lecce et al. 2001). It was suggested that the low $\operatorname{ER} \beta$ level is associated with the declined $\mathrm{P}_{4}$ concentration in this stage (Critchley et al. 2001). In the rhesus macaque endometrium during a hormonally controlled cycle (treated sequentially with $\mathrm{E}_{2}$ or $\mathrm{E}_{2}+\mathrm{P}_{4}$ for 14 days), the pattern of ER $\beta$ staining was identical to that seen in the human endometrium (Critchley et al. 2001). It is known that $\mathrm{P}_{4}$ induces proliferation of stromal cells (Finn \& Martin 1978). In the present study an increased immunoreactivity of ER $\beta$ was observed in the superficial stroma after MPA treatment. In addition, the increased ratio of ER $\beta / E R \alpha$ in the stroma after CEE/MPA treatment, and also after MPA treatment, suggests that the balance between these two receptors might determine the oestrogen response and indicate the rate of proliferation. However, the effects from MPA treatment on $\mathrm{ER} \beta / \mathrm{ER} \alpha$ expression are most probably secondary to progestin-mediated PR activity.

Combined treatment with CEE and MPA, as given in this study, reduced the ER $\beta$ protein in the basal stroma and glands, whereas the ER $\alpha$ level remained high. This suggests that ER $\alpha$ and $E R \beta$ are regulated differently in the functionalis and basalis of the endometrium after longterm hormone treatment. This lesser effect on ERs in response to steroids in the basal layer as compared with the functional layer is in agreement with recently published results from humans and monkeys during the menstrual cycle and a hormonally controlled cycle respectively (Critchley et al. 2001).

Previous studies on the rat uterus did not find any dominant effects on ER $\beta$ expression after short-term $E_{2}$ and/or $\mathrm{P}_{4}$ treatment (Shughrue et al. 1998, Wang et al. 1999). In addition, the lack of trophic responses to oestrogen in female ER $\alpha$ knock out $(\alpha E R K O)$ mice might suggest that $E R \beta$ plays a minor role in the rodent uterus. In immature $\beta E R K O$ mice, cell proliferation in the LE of the uterus was increased and cell responsiveness to $E_{2}$ was enhanced, which suggests an anti-uterotrophic role of ER $\beta$ and therefore an important role in regulating cellular proliferation in rodent uteri (Weihua et al. 2000). These data, together with ours, indicate that the steroid-mediated effects of the ERs in the endometrium are different after longand short-term treatment, and also in between species and/or developmental stage (e.g. immature or mature, premenopausal or postmenopausal).

The transcriptional activity of ERs in the oestrogen signalling pathways depends on dimerization, where the $\mathrm{ER} \alpha / \mathrm{ER} \alpha$ and $\mathrm{ER} \beta / \mathrm{ER} \beta$ homodimers, or $\mathrm{ER} \alpha / \mathrm{ER} \beta$ heterodimers, bind directly to the classical oestrogen responsive element (ERE) in the target genes (Pettersson et al. 1997). Varying ratios of $E R \alpha$ and $E R \beta$ in different 


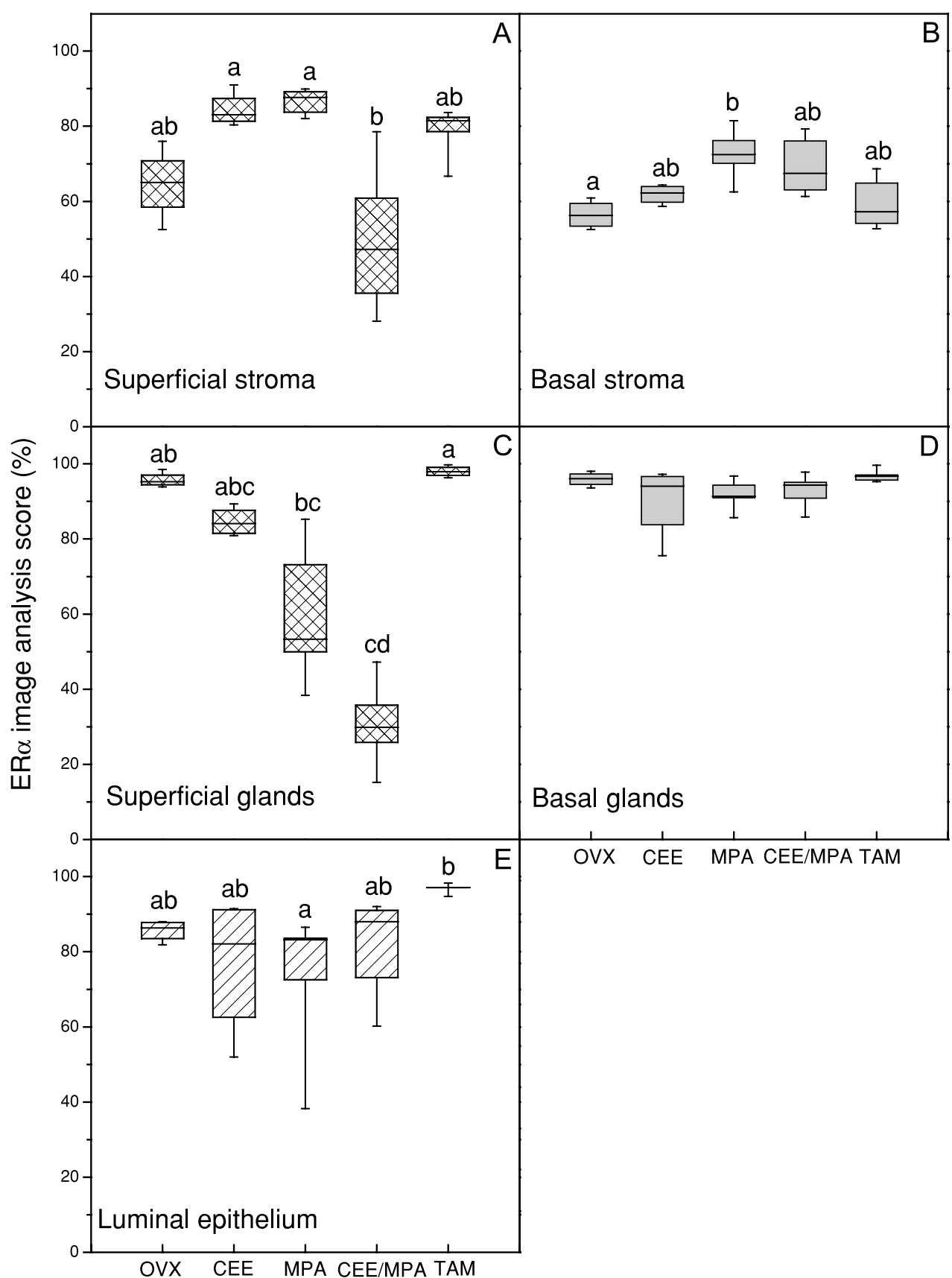

Figure 2 Image analysis scores of positive ER $\alpha$ immunoreactivity in superficial stroma (A), basal stroma (B), superficial glands (C), basal glands (D) and LE (E). Box and whisker plots representing the median value with $50 \%$ of all data falling within the box. The whiskers extend to the 5th and 95th percentiles. In OVX, MPA and CEE/MPA groups $n=5$, in CEE group $n=4$ and in the TAM group $n=6$. Values with different letter designations are significantly different $(P<0 \cdot 05)$.

cells result in different populations of homo- and heterodimers, which could constitute a mechanism for the tissueand cell type-specific actions of not only oestrogens, but also of anti-oestrogens (Kuiper \& Gustafsson 1997, Pettersson et al. 1997). The presence of both ER $\alpha$ and
ER $\beta$ in the macaque endometrium enables the formation of both homo- and heterodimers. Therefore, ER $\beta$ could act as a modulator of ER $\alpha$-mediated gene transcription in the uterus (Weihua et al. 2000), as indicated by the changes in ER $\beta / \mathrm{ER} \alpha$ ratios. 


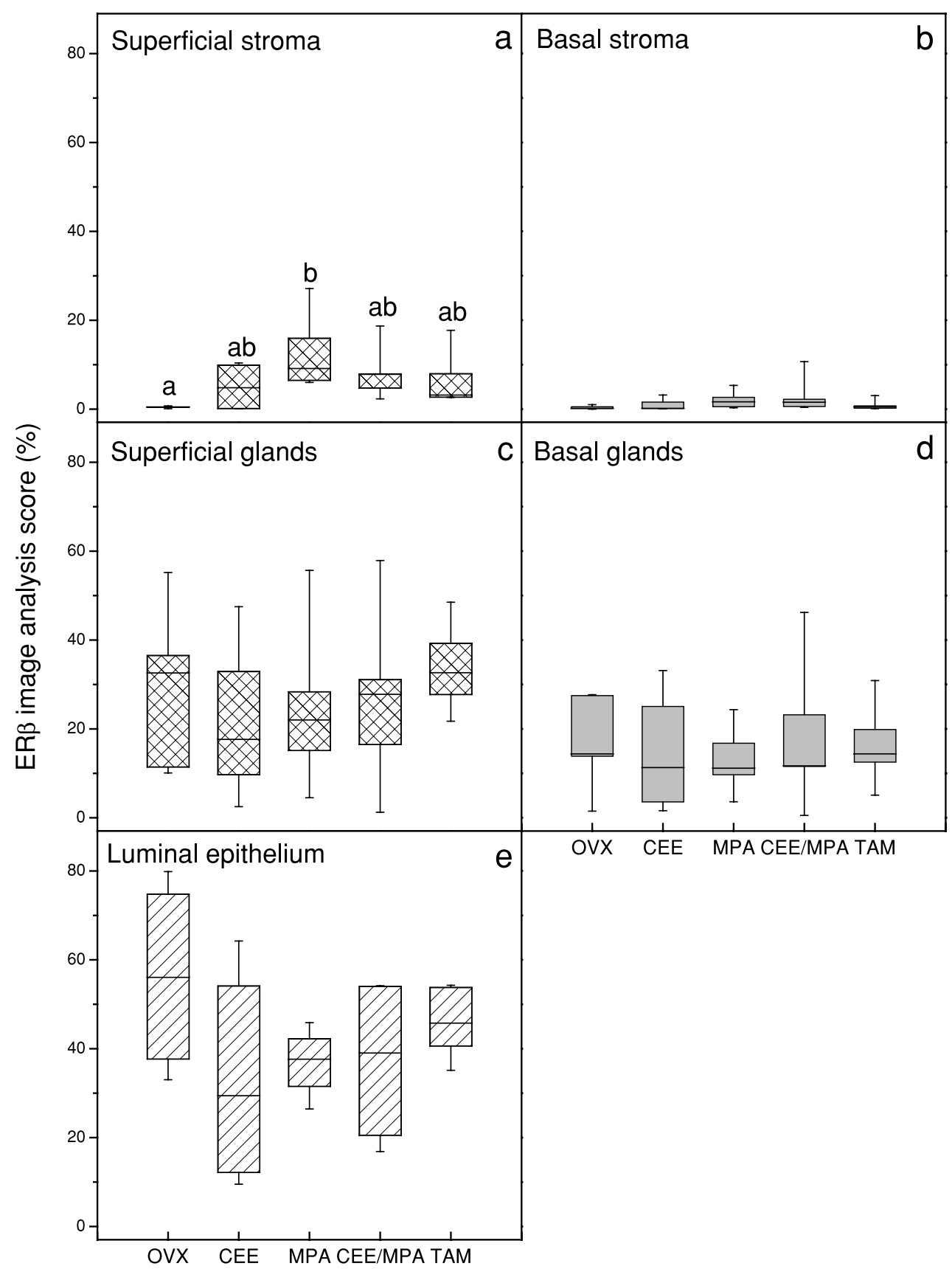

Figure 3 Image analysis scores of positive ER $\beta$ immunoreactivity in superficial stroma (a), basal stroma (b), superficial glands (c), basal glands (d) and LE (e). Box and whisker plots representing the median value with $50 \%$ of all data falling within the box. The whiskers extend to the 5th and 95th percentiles. $n=5$ in OVX, MPA and CEE/MPA groups (except LE, $n=3$ in CEE/MPA group since two samples lacked LE); $n=4$ in the CEE group; and $n=6$ in the TAM group. Values with different letter designations are significantly different $(P<0 \cdot 05)$.

TAM is used in breast cancer therapy and functions as an oestrogen antagonist by competing with oestrogen binding to ER, inhibiting the action of ER in breast tissue
(Jordan 1994). In the uterus, TAM acts as a partial oestrogen agonist. This tissue-specific agonistic effect may explain the increased risk of endometrial cancer that is 
Table 2 Ratios of ER $\beta / E R \alpha$ in the endometrium in the different study groups (means \pm S.E.M.)

\begin{tabular}{|c|c|c|c|c|c|}
\hline & OVX $(n=5)$ & CEE $(n=4)$ & MPA $(n=5)$ & CEE/MPA $(n=5)$ & $\operatorname{TAM}(n=6)$ \\
\hline Cell type & & & & & \\
\hline Superficial stroma & $0 \cdot 01 \pm 0.00$ & $0.06 \pm 0.03$ & $0 \cdot 15 \pm 0 \cdot 04$ & $0 \cdot 17 \pm 0 \cdot 06$ & $0 \cdot 08 \pm 0.03$ \\
\hline Basal stroma & $0 \cdot 01 \pm 0 \cdot 00$ & $0 \cdot 01 \pm 0 \cdot 01$ & $0 \cdot 03 \pm 0 \cdot 01$ & $0.05 \pm 0.03$ & $0 \cdot 02 \pm 0.00$ \\
\hline Basal GE & $0 \cdot 19 \pm 0.06$ & $0 \cdot 16 \pm 0 \cdot 07$ & $0 \cdot 14 \pm 0 \cdot 04$ & $0 \cdot 20 \pm 0 \cdot 08$ & $0 \cdot 17 \pm 0 \cdot 04$ \\
\hline LE & $0 \cdot 66 \pm 0 \cdot 13$ & $0 \cdot 41 \pm 0 \cdot 14$ & $0 \cdot 61 \pm 0 \cdot 20$ & $0 \cdot 50 \pm 0 \cdot 11$ & $0 \cdot 47 \pm 0.03$ \\
\hline
\end{tabular}

Table 3 Image analysis score (\%) of positive Ki67 staining cells in the stroma and gland (median and range). No significant differences were observed

\begin{tabular}{|c|c|c|c|c|c|}
\hline & OVX $(n=5)$ & CEE $(n=4)$ & MPA $(n=5)$ & CEE/MPA $(n=5)$ & TAM $(n=6)$ \\
\hline Superficial stroma & $0(0-1 \cdot 25)$ & $1(1-7)$ & $2(0 \cdot 75-7 \cdot 25)$ & $6(2-14)$ & $0(0-8 \cdot 75)$ \\
\hline Basal stroma & $0(0-3 \cdot 5)$ & $0(0-0)$ & $0(0-0 \cdot 5)$ & $0(0-3)$ & $0(0-0)$ \\
\hline Basal GE & $0(0-1)$ & $0(0-0)$ & $0(0-22 \cdot 75)$ & $0(0-1 \cdot 5)$ & $0(0-1 \cdot 75)$ \\
\hline
\end{tabular}

observed with prolonged TAM therapy (Kedar et al. 1994). In vitro studies have demonstrated that the agonistic effect of TAM depends on the cell type, ERE-promoter context and ER subtype (Watanabe et al. 1997), and that it is also mediated by the ER/AP-1 pathway (Webb et al. 1995).

$\mathrm{ER} \beta$ can function as a transdominant inhibitor of $\mathrm{ER} \alpha$ transcriptional activity at sub-saturating hormone levels and to decrease overall cellular sensitivity to $\mathrm{E}_{2}$ in vitro (Hall \& McDonnell 1999). The partial agonistic activity of TAM manifest via $\operatorname{ER} \alpha$ was completely abolished upon coexpression of $\operatorname{ER} \beta$ with $\operatorname{ER} \alpha$ (Hall \& McDonnell 1999). We speculate that a reduced repression from ER $\beta$ results in an unopposed proliferation from ER $\alpha$ activity, an effect that could be responsible for the increased risk of endometrial carcinoma after TAM treatment. When looking at the ratios of $\operatorname{ER} \beta / \operatorname{ER} \alpha$ immunoreactivity in the different groups, TAM treatment showed an increased level only in the superficial stroma as compared to OVX. However, the regulation and relationship between the two subtypes of ER are more complicated in vivo than in vitro since there are many factors directly or indirectly involved in the endocrine system.

In conclusion, the present data further confirm that the multifunctional activities of oestrogen and progestin in the uterus are mediated by a complex regulation of ERs (Tibbetts et al. 1998, Wang et al. 1999) in the different compartments. This is, to our knowledge, the first study on the effect of long-term hormone treatment on the expression of $\mathrm{ER} \beta$ in primate endometrium. $\mathrm{ER} \beta$ levels vary less than those of $\operatorname{ER} \alpha$. In addition, $\operatorname{ER} \beta$ is distributed predominantly in the functionalis of the endometrium, while ER $\alpha$ is found in considerable amounts also in the basalis. The endometrial hyperplasia found after TAM treatment could be due to the increased ER $\alpha$ level observed in the present study. The ratio of
$\mathrm{ER} \beta / \mathrm{ER} \alpha$ after the different treatments could determine the oestrogen response and indicate the rate of proliferation. Thus, ER $\beta$ might be of importance in repressing the proliferative activity of $\operatorname{ER} \alpha$. Further studies are needed to determine the importance of $\operatorname{ER} \beta / \operatorname{ER} \alpha$ interactions for proliferative activity in the endometrium and possible side-effects of HRT and TAM therapy.

\section{Acknowledgements}

We are grateful for excellent technical assistance from Britt Masironi, and to Håkan Eriksson for valuable comments on the manuscript. The ER $\beta 503$ antibody was kindly provided by Jan-Åke Gustafsson, Department of Medical Nutrition, Novum, Huddinge, Sweden.

\section{References}

Ace CI \& Okulicz WC 1995 Differential gene regulation by estrogen and progesterone in the primate endometrium. Molecular and Cellular Endocrinology 115 95-103.

Adams MR, Register TC, Golden DL, Wagner JD \& Williams JK 1997 Medroxyprogesterone acetate antagonizes inhibitory effects of conjugated equine estrogens on coronary artery arteriosclerosis. Arteriosclerosis, Thrombosis, and Vascular Biology 17 217-221.

Brenner RM \& Slayden OD 1994 Cyclic changes in the primate oviduct and endometrium. In The Physiology of Reproduction, pp 541-569. Eds E Knobil \& JD Neill. New York: Raven Press.

Brenner RM, West NB \& MaClellan MC 1990 Estrogen and progestin receptors in the reproductive tract of male and female primates. Biology of Reproduction 42 11-19.

Clark JH, Schrader WT \& O’Malley BW 1992 In Mechanism of Action of Steroid Hormones, Textbook of Endocrinology, pp 35-90. Ed. J Wilson. Philadelphia, PA: WB Saunders Company.

Cline M, Söderqvist G, Register TC, Williams JK, Adams MR \& Schoultz BV 2001 Assessment of hormonally active agents in the reproductive tract of female nonhuman primates. Toxicologic Pathology 29 84-90. 
Critchley HO, Brenner RM, Henderson TA, Williams K, Nayak NR, Slayden OD, Millar MR \& Saunders PT 2001 Estrogen receptor $\beta$, but not estrogen receptor $\alpha$, is present in the vascular endothelium of the human and nonhuman primate endometrium. Journal of Clinical Endocrinology and Metabolism 86 1370-1378.

Dickson RB \& Lippman ME 1987 Estrogenic regulation of growth and polypeptide growth factor secretion in human breast carcinoma. Endocrine Reviews 8 29-43.

Finn CA \& Martin L 1978 Effects of a long-acting progestin on reproductive function in female mice. Journal of Endocrinology 79 235-238.

Grady D, Rubin SM, Petitti DB, Black D, Ettinger B, Ernster VL \& Cummings SR 1992 Hormone therapy to prevent disease and prolong life in postmenopausal women. Annals of International Medicine 117 1016-1037.

Grady D, Gebretsadik T, Kerlikowske K, Ernster V \& Petitti D 1995 Hormone replacement therapy and endometrial cancer risk: a meta-analysis. Obstetrics and Gynecology 85 304-313.

Hall JM \& McDonnell DP 1999 The estrogen receptor $\beta$-isoform $(\mathrm{ER} \beta)$ of the human estrogen receptor modulates ER alpha transcriptional activity and is a key regulator of the cellular response to estrogens and antiestrogens. Endocrinology 140 5566-5578.

Helgason S, Wilking N, Carlstrom K, Damber MG \& von Schoultz B 1982 A comparative study of the estrogenic effects of tamoxifen and 17 beta-estradiol in postmenopausal women. Journal of Clinical Endocrinology and Metabolism 54 404-408.

Henderson BE, Ross RK, Pike MC \& Casagrande JT 1982 Endogenous hormones as a major factor in human cancer. Cancer Research 42 3232-3239.

Jordan VC 1994 Molecular mechanisms of antiestrogen action in breast cancer. Breast Cancer Research and Treatment 31 41-52.

Katzenellenbogen JA \& Katzenellenbogen BS 1996 Nuclear hormone receptors: ligand-activated regulators of transcription and diverse cell responses. Chemistry and Biology 3 529-536.

Kedar RP, Bourne TH, Powles TJ, Collins WP, Ashley SE, Cosgrove DO \& Campbell S 1994 Effects of tamoxifen on uterus and ovaries of postmenopausal women in a randomised breast cancer prevention trial. Lancet 343 1318-1321.

Kuiper GGJM \& Gustafsson J-A 1997 The novel estrogen receptor- $\beta$ subtype: potential role in the cell- and promoter-specific actions of estrogens and anti-estrogens. FEBS Letters 410 87-90.

Kuiper GGJM, Enmark E, Pelto-Huikko M, Nilsson S \& Gustafsson J-Å 1996 Cloning of a novel receptor expressed in rat prostate and ovary. PNAS 93 5925-5930.

Lane G, Siddle NC, Ryder TA, Pryse-Davies J, King RJB \& Whitehead MI 1986 Is Provera the ideal progesterone for addition to postmenopausal estrogen therapy? Fertility and Sterility $\mathbf{4 5}$ 345-352.

Langan-Fahey SM, Tormey DC \& Jordan VC 1990 Tamoxifen metabolites in patients on long-term adjuvant therapy for breast cancer. European Journal of Cancer 26 883-888.

Lecce G, Meduri G, Ancelin M, Bergeron C \& Perrot-Applanat M 2001 Presence of estrogen receptor $\beta$ in the human endometrium through the cycle: expression in glandular, stromal, and vascular cells. Journal of Clinical Endocrinology and Metabolism 86 1379-1386.

Malfetano JH 1990 Tamoxifen-associated endometrial carcinoma in postmenopausal breast cancer patients. Gynecologic Oncology 39 $82-84$.

Matsuzaki S, Fukaya T, Suzuki T, Murakami T, Sasano H \& Yajima A 1999 Oestrogen receptor $\alpha$ and $\beta$ mRNA expression in human endometrium throughout the menstrual cycle. Molecular Human Reproduction 5 559-564.
Murphy LJ \& Ghahary A 1990 Uterine insulin-like growth factor-I: regulation of expression and its role in estrogen-induced uterine proliferation. Endocrine Reviews 11 443-453.

Pelletier G, Luu-The V, Charbonneau A \& Labrie F 1999 Cellular localization of estrogen receptor $\beta$ messenger ribonucleic acid in cynomolgus monkey reproductive organs. Biology of Reproduction $\mathbf{6 1}$ 1249-1255.

Persson I 2000 Estrogens in the causation of breast, endometrial and ovarian cancers - evidence and hypotheses form epidemiological findings. Journal of Steroid Biochemistry and Molecular Biology $\mathbf{7 4}$ 357-364

Pettersson K, Grandien K, Kuiper GGJM \& Gustafsson J-Å 1997 Mouse estrogen receptor $\beta$ forms estrogen response element-binding heterodimers with estrogen receptor $\alpha$. Molecular Endocrinology 11 1486-1496.

Pike MC \& Ross RK 2000 Progestins and menopause: epidemiological studies of risks of endometrial and breast cancer. Steroids 65 659-664.

Rose C, Thorpe SM, Andersen KW, Pedersen BV, Mouridsen HT, Blichert-Toft M \& Rasmussen BB 1985 Beneficial effect of adjuvant tamoxifen therapy in primary breast cancer patients with high oestrogen receptor values. Lancet 1 16-19.

Saji S, Jensen EV, Nilsson S, Rylander T, Warner M \& Gustafsson JA 2000 Estrogen receptors $\alpha$ and $\beta$ in the rodent mammary gland. PNAS 97 337-342.

Shughrue PJ, Lane MV, Scrimo PJ \& Merchenthaler I 1998 Comparative distribution of estrogen receptor- (ER-) and (ER-) mRNA in the rat pituitary, gonad, and reproductive tract. Steroids 63 498-504.

Tibbetts TA, Mendoza-Meneses M, O’Malley BW \& Conneely OM 1998 Mutual and intercompartmental regulation of estrogen receptor and progesterone receptor expression in the mouse uterus. Biology of Reproduction 59 1143-1152.

Vihko R \& Isomaa V 1989 Endocrine aspects of endometrial cancer. In Endocrine Dependent Tumors, pp 197-212. Eds K Voight \& C Knabbe. New York: Raven Press.

Wang H, Masironi B, Eriksson H \& Sahlin L 1999 A comparative study of estrogen receptors $\alpha$ and $\beta$ in the rat uterus. Biology of Reproduction 61 955-964.

Wang H, Stjernholm Y, Ekman G, Eriksson H \& Sahlin L 2001 Different regulation of oestrogen receptors $\alpha$ and $\beta$ in the human cervix at term pregnancy. Molecular Human Reproduction 7 293-300.

Watanabe T, Inoue S, Ogawa S, Ishii Y, Hiroi H, Ikeda K, Orimo A \& Muramatsu M 1997 Agonistic effect of tamoxifen is dependent on cell type, ERE-promoter context, and estrogen receptor subtype: functional difference between estrogen receptors $\alpha$ and $\beta$. Biochemical and Biophysical Research Communications 236 140-145.

Webb P, Lopez GN, Uht RM \& Kushner PJ 1995 Tamoxifen activation of the estrogen receptor/AP-1 pathway: potential origin for the cell-specific estrogen-like effects of antiestrogens. Molecular Endocrinology 9 443-456.

Weihua Z, Saji A, Mäkinen S, Cheng G, Jensen EV, Warner M \& Gustafsson J-A 2000 Estrogen receptor (ER) $\beta$, a modulator of ER $\alpha$ in the uterus. PNAS 97 5936-5941.

Wilson ME, Gordon TP, Rudman CG \& Tanner JM 1988 Effects of a natural versus artificial environment on the tempo of maturation in female rhesus monkeys. Endocrinology 123 2653-2661.

Received 25 July 2002

Accepted 1 August 2002 